\title{
Correction: The key role of repeated DNAs in sex chromosome evolution in two fish species with ZW sex chromosome system
}

Marcelo de Bello Cioffi ${ }^{*}$, Eduard Kejnovský ${ }^{2,3}$, Vinicius Marquioni ${ }^{1}$, Juliana Poltronieri ${ }^{1}$, Wagner F Molina ${ }^{4}$, Débora Diniz ${ }^{5}$ and Luiz Antonio C Bertollo ${ }^{1}$

\section{Correction}

After the publication of this work [1] the following errors were brought to the authors' attention: Figure 1 contained a misspelling of the species name Leporinus reinhardti, and Figures 2 and 3 contained mistakes that occurred during the editing process. The correct figures are given below.

We regret any inconvenience that this inaccuracy may have caused.

\footnotetext{
* Correspondence: mbcioffi@ufscar.br

${ }^{1}$ Departamento de Genética e Evolução, Universidade Federal de São Carlos, São Carlos, SP, Brazil

Full list of author information is available at the end of the article
} 


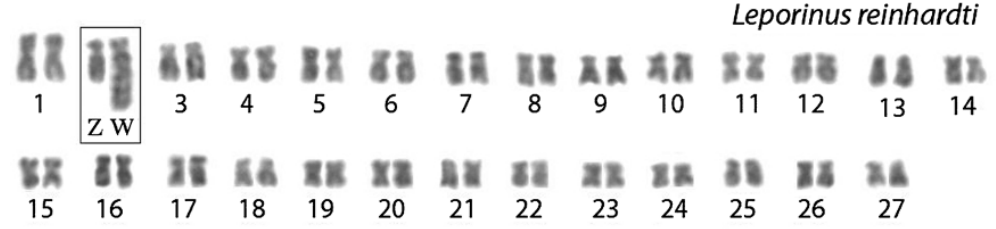

Triportheus auritus

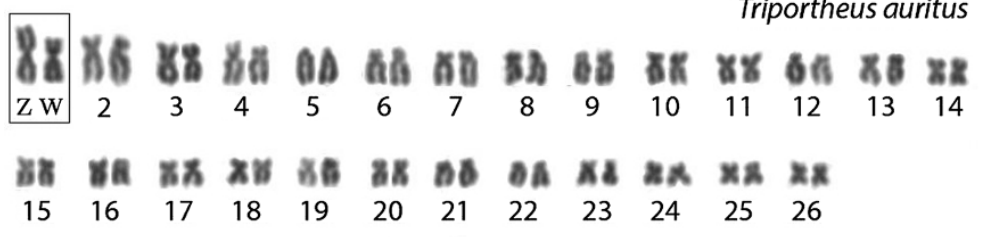

Figure 1 Giemsa-stained female karyotypes of Leporinus reinhardti $(2 n=54)$ and Triportheus auritus $(2 n=52)$, both with a ZZ/ZW sex chromosome system. The chromosomes of both species were arranged in descending order of size and the sex chromosomes were highlighted in boxes for the sake of clarity. Bar $=5 \mu \mathrm{m}$.
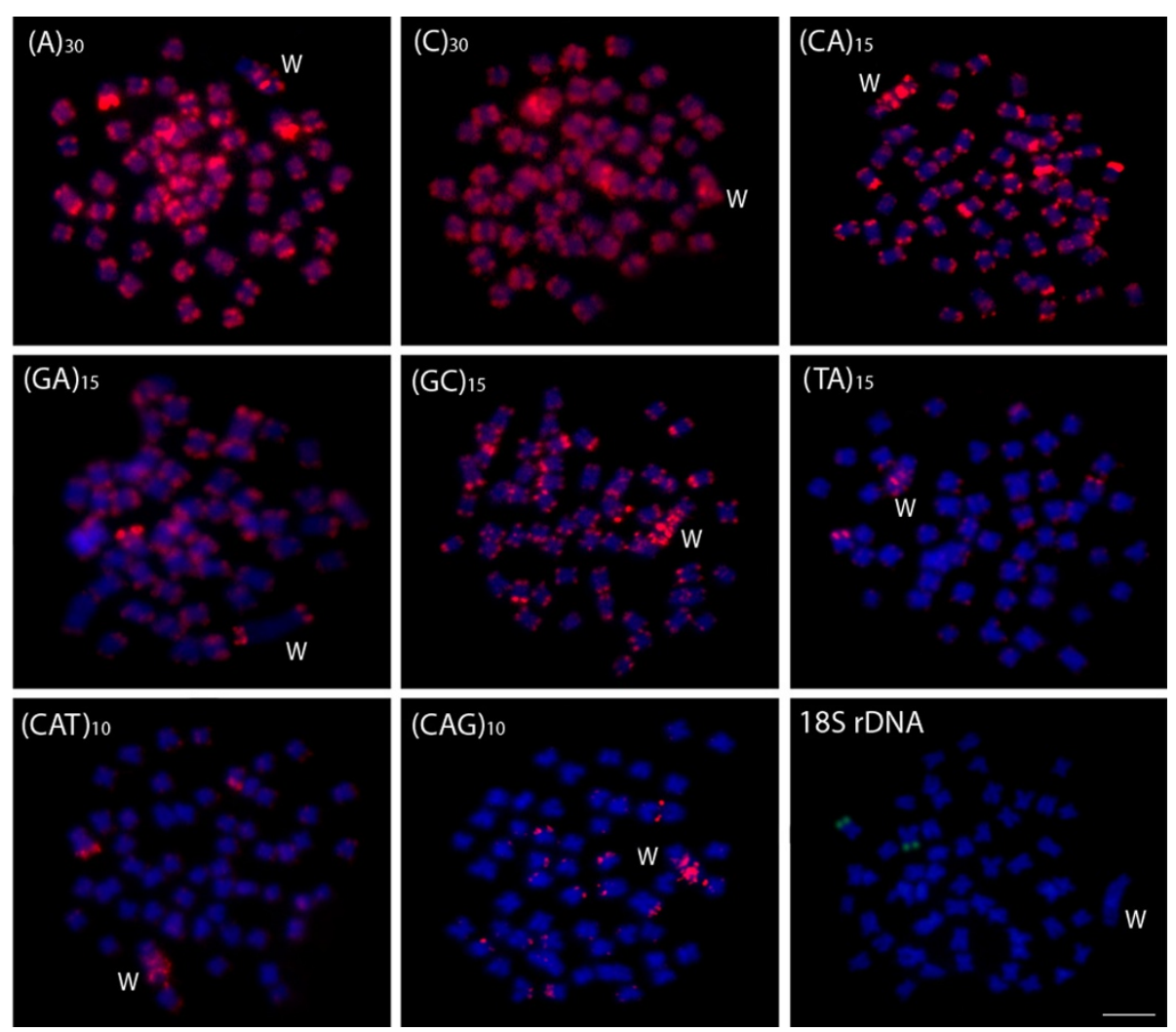

Figure 2 Mitotic metaphase chromosomes of Leporinus reinhardti female, with a ZZ/ZW sex chromosome system hybridized with different repeated DNAs, including mono-, di- and trinucleotide microsatellites and an 18S rDNA gene as probes. Letters mark the W chromosomes. Bar $=5 \mu \mathrm{m}$. 


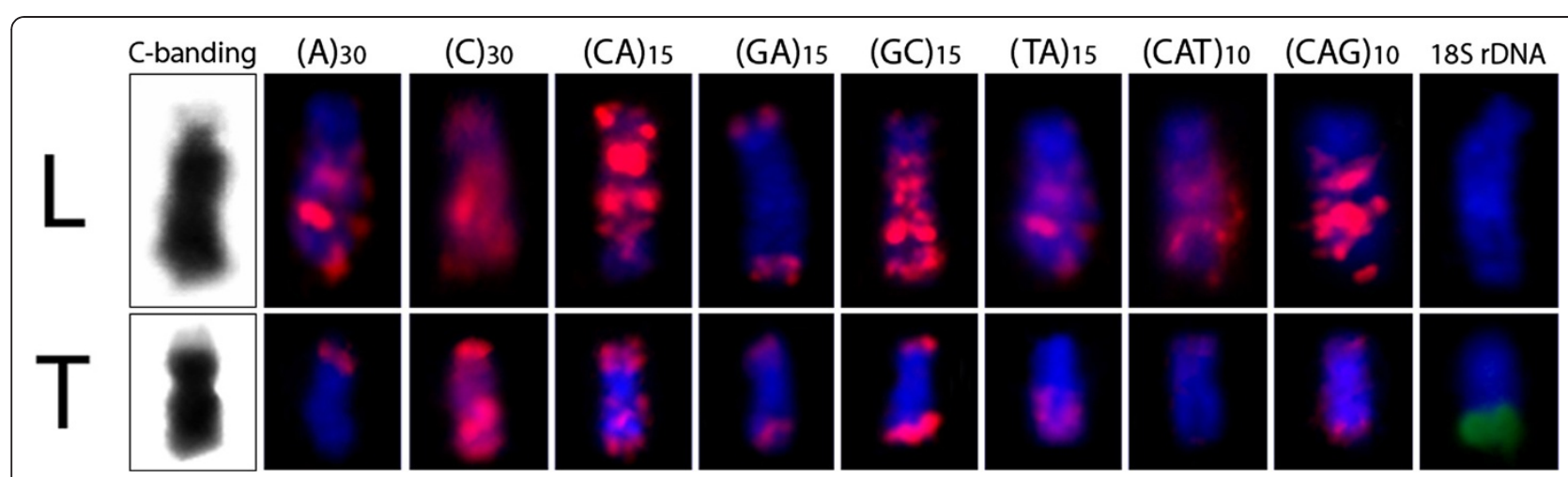

Figure $3 \mathrm{~W}$ chromosomes of Leporinus reinhardti (L) and Triporteus auritus (T) after C-banding and FISH with various repetitive DNA sequences. Note the huge accumulation of several classes of microsatellites in L. reinhardti and the lesser amount of this accumulation in T. auritus.

\section{Author details}

'Departamento de Genética e Evolução, Universidade Federal de São Carlos, São Carlos, SP, Brazil. ²Department of Plant Developmental Genetics, Institute of Biophysics ASCR, Brno, Czech Republic. ${ }^{3}$ Laboratory of Genome Dynamics, CEITEC - Central European Institute of Technology, Masaryk University, Brno, Czech Republic. ${ }^{4}$ Departamento de Biologia Celular e Genética, Centro de Biociências, Universidade Federal do Rio Grande do Norte, Natal, RN, Brazil. ${ }^{5}$ Departamento de Ciências Biológicas, Universidade Estadual do Sudoeste da Bahia, Jequié, BA, Brazil.

Received: 23 November 2012 Accepted: 23 November 2012 Published: 27 November 2012

\section{References}

1. Cioffi MB, Kejnovsky E, Marquioni V, Poltronieri J, Molina WF, Diniz D, Bertollo LAC: The key role of repeated DNAs in sex chromosome evolution in two fish species with ZW sex chromosome system. Mol Cytogenet 2012, 5:28.

doi:10.1186/1755-8166-5-42

Cite this article as: Cioffi et al:: Correction: The key role of repeated DNAs in sex chromosome evolution in two fish species with ZW sex chromosome system. Molecular Cytogenetics 2012 5:42.

\section{Submit your next manuscript to BioMed Central and take full advantage of:}

- Convenient online submission

- Thorough peer review

- No space constraints or color figure charges

- Immediate publication on acceptance

- Inclusion in PubMed, CAS, Scopus and Google Scholar

- Research which is freely available for redistribution

Submit your manuscript at www.biomedcentral.com/submit 